\title{
Peningkatan Kemampuan Menulis Teks Persuasi dengan Menggunakan Teknik Pemodelan Siswa Kelas VIII SMPN L Sidoharjo Kabupaten Musi Rawas
}

\author{
Elpi Arida $^{* 1}$, Susetyo ${ }^{2}$, Didi Yulistio ${ }^{3}$ \\ Program Magister Pendidikan Bahasa Indonesia, Universitas Bengkulu \\ Corresponding email: elpiarida98@gmail.com*
}

\begin{abstract}
The purpose of this study was to describe (1) increasing the ability to write persuasion text with the modeling techniques of eighth grade students of SMPN L. Sidoharjo, Musi Rawas Regency and (2) Increasing student learning activities in writing persuasive text with modeling techniques for VIII students of SMPN L. Sidoharjo, Musi Regency Rawas. This study uses a Classroom Action Research (CAR) procedures. This research was conducted in two cycles. Each cycle is designed and carried out by steps (1) planning, (2) action, (3) observation, and (4) reflection. The source of the data of this study was the eighth grade students of SMP N L. Sidoharjo in the 2018/2019 academic year, while the research data were in the form of persuasion texts written by students. Then the data is analyzed using the average formula and the results are consulted in the qualification table. The results showed that the ability to write persuasion texts students experienced an average increase in cycle 1 of 67.98 which included in the category of enough, increased to 77,76 in the second cycle included in the good category. The increase was also followed by an increase in student activity in learning to write persuasion texts which included activeness and direct involvement in observing, answering questions and writing persuasion texts from moderately active to active.
\end{abstract}

Keywords: the ability to write persuasion texts, modeling techniques

\begin{abstract}
Abstrak
Tujuan penelitian ini mendeskripsikan: (1) peningkatan kemampuan menulis teks persuasi dengan teknik pemodelan siswa kelas VIII SMPN L. Sidoharjo Kabupaten Musi Rawas dan (2) peningkatan aktivitas belajar siswa dalam menulis teks persuasi dengan teknik pemodelan siswa kelas VIII SMPN L. Sidoharjo Kabupaten Musi Rawas. Penelitian ini merupakan Penelitian Tindakan Kelas (PTK). Penelitian ini dilaksanakan dalam dua siklus. Tiap-tiap siklus dirangcang dan dilaksanakan dengan langkah-langkah (1) perencanaan, (2) tindakan, (3) pengamatan, dan (4) refleksi. Sumber data penelitian ini adalah siswa kelas VIII SMP N L. Sidoharjo tahun pelajaran 2018/2019, sedangkan data penelitian berupa teks persuasi hasil tulisan siswa. Data dianalisis dengan menggunakan rumus rata-rata dan hasilnya dikonsulitasikan pada tabel kualifikasi. Hasil penelitian menunjukkan bahwa kemampuan menulis teks persuasi siswa meningkat dengan rata-rata pada siklus 1 sebesar 67.98
\end{abstract}


termasuk pada kategori cukup, meningkat menjadi 77,76 pada siklus II termasuk pada kategori baik. Peningkatan tersebut juga diikuti dengan meningkatnya aktivitas siswa dalam pembelajaran menulis teks persuasi yang meliputi keaktifan dan keterlibatan langsung dalam melakukan pengamatan, tanya jawab, dan menulis teks persuasi dari cukup aktif menjadi aktif.

Kata kunci: kemampuan menulis teks persuasi, teknik pemodelan

\section{PENDAHULUAN}

Pembelajaran bahasa Indonesia dalam Kurikulum 2013 adalah pembelajaran berbasis teks. Teks merupakan ungkapan pikiran manusia yang lengkap yang di dalamnya memiliki situasi dan konteks sebagai realisasi dari sistem nilai dan norma serta berbasis karakter mulia (Ramadania, 2016:228; Rahayu \& Rochmiyati, 2019:175; Sahri, 2015:66). Pembelajaran bahasa Indonesia berbasis teks bertujuan agar peserta didik mampu mengembangkan mentalnya dan menyelesaikan masalah kehidupan nyata melalui proses berpikir kritis, berkolaborasi, kerja sama, dan kreatif (Noermanzah \& Friantary, 2019:6631). Pembelajaran bahasa Indonesia menerapkan pembelajaran berbasis teks yang didasarkan pada empat prinsip. Prisip-prinsip itu meliputi: (1) bahasa hendaknya dipandang sebagai teks, bukan semata-mata kumpulan kata atau kaidah kebahasaan; (2) penggunaan bahasa merupakan proses pemilihan bentuk-bentuk kebahasan untuk mengungkapkan makna; (3) bahasa bersifat fungsional, artinya penggunaan bahasa yang tidak pernah dapat dipisahkan dari konteks, karena bentuk bahasa yang digunakan mmencerminkan ide, sikap, nilai, dan ideologi pemakai/penggunanya; dan (4) bahasa merupakan sarana pembentukan berpikir manusia (Kemendikbud dalam Suryani dkk., 2014:2; Noermanzah, 2019:307-308).

Dengan prinsip di atas, pembelajaran bahasa berbasis teks membawa implikasi metodologis pada pembelajaran yang bertahap. Hal ini diawali dari kegiatan guru membangun konteks, dilanjutkan dengan kegiatan pemodelan, membangun teks secara bersama-sama, sampai pada membangun teks secara mandiri. Kegiatan ini dilakukan karena teks merupakan satuan bahasa yang mengandung pikiran dengan struktur yang lengkap. Guru harus benar-benar meyakini bahwa pada akhirnya peserta didik mampu menyajikan teks secara mandiri (Mahsun, 2014: 39).

Pembelajaran berbasis teks ini didasarkan pada fakta yang menunjukkan bahwa manusia hidup dalam dunia kata-kata, bila kata-kata dirangkai untuk mengomunikasikan gagasan/makna, maka sebenarnya seseorang telah menciptakan sebuah teks. Di dalam Kurikulum 2013 terdapat berbagai jenis teks, salah satunya teks persuasi. Teks persuasi merupakan sebuah teks yang bertujuan untuk mengajak, menyuruh, atau membujuk pembacanya melakukan sesuatu sesuai dengan apa yang disampaikan oleh penulis (Tabelessy, 2019:44; Suryani dkk., 2014:2). Tulisan pada teks persuasi bersifat subjektif karena isinya merupakan murni pandangan pribadi penulisnya mengenai suatu topik. Maka, tidak jarang dalam teks persuasi ditemukan data-data pendukung lain untuk mendukung tulisan tersebut sehingga pembaca tidak ragu untuk melakukan apa yang ditulis oleh penulis.

Salah satu kompetensi yang harus dicapai oleh siswa adalah menulis teks persuasi yang terdapat pada KD.4.14: menyajikan teks persuasi (saran, ajakan, arahan, dan pertimbangan) secara tulis dan lisan dengan memperhatikan struktur, kebahasaan, atau aspek lisan. Apabila siswa telah mencapai kompetensi tersebut, 
maka siswa telah mampu dalam menyusun teks persuasi sesuai dengan karakteristik teks tersebut.

Tujuan kompetensi dasar adalah mengasah pengalaman dan daya imajinasi siswa dalam menyusun teks persuasi secara tertulis. Dengan adanya pembelajaran teks persuasi, siswa diharapkan dapat berlatih dalam mengungkapkan apa yang dilihat, didengar, dan dirasakannya. Siswa diharuskan mempunyai pengamatan yang tajam dan memanfaatkan semua alat inderanya secara maksimal. Tujuan penulisan teks persuasi yaitu penulis mampu memengaruhi, meyakinkan, dan mengubah pikiran pembaca sehingga mereka menyetujui dan melaksanakan pendapat yang ditulis. Oleh karena itu, diperlukan data sebagai penunjang untuk meyakinkan pembaca akan tulisan persuasi yang dibuat dapat diikuti pembaca. Data yang digunakan dalam tulisan atau paragraf persuasi lebih baik berupa fakta. Jika hal-hal itu diperhatikan, maka akan tercipta daya persuasi yang baik. Pada kenyataannya, pembelajaran menulis teks persuasi di kelas VIII SMP Negeri L Sidoharjo masih rendah. Hal tersebut terbukti bahwa keterampilan menulis siswa khususnya menulis teks persuasi masih di bawah kriteria ketuntasan minimal (KKM). KKM untuk Mata Pelajaran Bahasa Indonesia di kelas VIII.2 adalah 67, namun skor rata-rata kelas VIII.2 SMPN L Sidoharjo 65. Berdasarkan skor rata-rata yang dicapai siswa dapat diketahui jumlah siswa yang tuntas hanya mencapai 7 orang $(21,9 \%)$ dan 25 orang $(78,1 \%)$ tergolong belum tuntas. Hal ini menandakan bahwa sebagian besar siswa belum tuntas dalam pembelajaran menulis teks persuasi.

Berdasarkan hasil observasi awal yang peneliti lakukan di kelas VIII.2 SMP Negeri L Sidoharjo, diketahui bahwa siswa masih kesulitan menulis teks persuasi. Hal ini didukung dari hasil wawancara terhadap beberapa siswa kelas VIII.2, diperoleh informasi bahwa siswa masih mengalami kesulitan dalam menentukan struktur teks persuasi dan kesulitan dalam memanfaatkan diksi persuasif ke dalam paragraf. Hal ini menandakan bahwa minimnya pengetahuan siswa tentang cara menulis teks persuasi.

Dalam mengelola pembelajaran, kemahiran seorang guru sangat berpengaruh terhadap berhasilnya pencapaian hasil belajar siswa (Noermanzah, 2015:274). Mengingat kompleksnya pengetahuan dan keterampilan yang perlu dimiliki seorang penulis yang baik. Dalam pembelajaran, guru dituntut memilih teknik yang dapat mengarahkan siswa memperoleh pengetahuan sekaligus keterampilan menulis. Teknik yang dipilih oleh guru hendaknya dapat membuat siswa memperoleh contoh tulisan yang benar, mengenali dan memahami unsur-unsur menulis, cara menulis dengan benar sehingga siswa dapat mengetahui, memahami, serta dapat menulis dengan benar pula.

Berdasarkan permasalahan di atas, salah satu teknik yang dapat diterapkan untuk meningkatkan keterampilan menulis teks persuasi adalah teknik pemodelan. Pemodelan dapat diartikan sebagai upaya pemberian contoh (model) yang berhubungan dengan materi dan aktivitas pembelajaran yang dilakukan siswa (Nuryatin, 2010:34: Suryani dkk., 2014:3). Sejalan dengan pernyataan tersebut, Nurhadi (2004:16) mengungkapkan bahwa teknik pemodelan merupakan pembelajaran keterampilan atau pengetahuan tertentu dengan menggunakan contoh (model) yang bisa ditiru. Teknik pemodelan pada prinsipnya memiliki tujuan untuk membahasakan gagasan yang kita pikirkan, mendemonstrasikan bagaimana guru menginginkan para siswanya untuk belajar, dan melakukan apa yang guru harapkan 
agar siswa-siswanya melakukan keinginan guru sesuai tujuan pembelajaran (Fitri, 2016:120).

Dengan demikian, siswa akan belajar melalui contoh (model) yang diberikan oleh guru. Pemberian model dilakukan dengan memberikan sebuah contoh teks persuasi untuk ditiru, bukan kata demi kata atau kalimat demi kalimat, tetapi cara atau teknik pengembangan paragrafnya. Dalam hal ini, teknik pemodelan berangkat dari pemberian contoh (model) paragraf, membaca teks model, menganalisis teks model, dan berlatih menulis dengan meniru konstruksi teks model. Oleh karena itu, guru bukan lagi satu-satunya sumber belajar bagi siswa melainkan siswa lebih aktif untuk mengembangkan pengetahuannya sehingga mendorong terjadinya proses belajar pada diri sendiri. Pemodelan akan membuat siswa memperoleh contoh teks yang benar. Melalui teknik ini siswa dapat membangun pengetahuannya tentang cara menulis yang benar.

Penelitian mengenai menulis teks persuasi juga dilakukan oleh Ernawati (2009) yang berjudul Peningkatan Keterampilan Menulis Iklan melalui Teknik Pemodelan Pada Siswa Kelas VII-D SMP 2 Wanadadi Kabupaten Banjarnegara. Penggunaan teknik pemodelan menunjukkan adanya peningkatan hasil tes keterampilan menulis iklan siswa. Hasil rata-rata tes keterampilan menulis iklan siklus I adalah 76,33. Nilai tes tersebut meningkat sebesar $20,72 \%$ dari hasil prasiklus yang semula hanya 63,2. Pada siklus II hasil rata-rata tes keterampilan menulis iklan meningkat lagi sebesar $6,28 \%$ dari siklus I menjadi 81,13 . Melalui penggunaan teknik pemodelan juga terjadi perubahan perilaku siswa lebih antusias pada pembelajaran dan termotivasi. Siswa juga menjadi tidak malas untuk menulis iklan. Dengan demikian, pembelajaran melalui teknik pemodelan dapat meningkatkan keterampilan menulis iklan serta dapat mengubah perilaku belajar siswa kelas VII-D SMP Negeri 2 Wanadadi Kabupaten Banjarnegara. Pembelajaran ini dapat dijadikan alternatif dalam pembelajaran menulis iklan.

Dari penelitian relevan di atas, teknik pemodelan belum diterapkan pada peningkatan kemampuan menulis teks persuasi. Untuk itu, penulis bermaksud mengadakan penelitian tentang peningkatan keterampilan menulis teks persuasi dengan menggunakan teknik pemodelan siswa kelas VIII SMP Negeri L Sidoharjo Kecamatan Tugumulyo Kabupaten Musi Rawas tahun pelajaran 2018/2019.

\section{METODE}

Penelitian ini menggunakan metode penelitian tindakan kelas untuk menggambarkan kemampuan menulis teks persuasi dengan menggunakan teknik pemodelan siswa kelas VIII SMP Negeri L. Sidoharjo Kabupaten Musi Rawas Tahun Pelajaran 2018/2019. Tujuan penelitian ini untuk mengamati, mempersepsikan, dan menginterpretasikan peningkatan kemampuan menulis teks persuasi dengan menggunakan teknik pemodelan siswa kelas VIII SMP Negeri L. Sidoharjo Kabupaten Musi Rawas. Pemilihan pendekatan deskriptif kuantitatif didasarkan pada pertimbangan untuk menelusuri secara mendalam mengenai peningkatan kemampuan menulis teks persuasi dengan menggunakan teknik pemodelan siswa kelas VIII SMP Negeri L. Sidoharjo Kabupaten Musi Rawas.

Penelitian ini dilaksanakan di kelas VIII.2 SMP Negeri L. Sidiharjo Kabupaten Musi Rawas yang terletak di Jalan Punto Dewo Desa L Sidoharjo Kecamatan Tugumulyo Kabupaten Musi Rawas. Penelitian ini dilaksanakan pada tanggal 26 Maret sampai dengan 16 April 2019, semester genap tahun pelajaran 2018/2019. 
Data dalam penelitian ini adalah kemampuan menulis teks persuasi, sedangkan sumber datanya adalah siswa kelas VIII.2 SMP Negeri L. Sidoharjo tahun pelajaran 2018/2019, yang berjumlah 32 siswa, terdiri atas 14 orang laki-laki dan 18 orang perempuan. Pemilihan kelas VIII.2 sebagai sumber data didasarkan pada pertimbangan bahwa pada saat prapenelitian, permasalahan ditemukan pada kelas tersebut dimana aktivitas dan kemampuan menulis teks persuasi siswa masih rendah.

Prosedur penelitian ini adalah penelitian tindakan kelas (PTK). Menurut Arikunto dkk., (2012:9), penelitian tindakan kelas adalah suatu penelitian yang bertujuan untuk memperbaiki mutu proses belajar mengajar yang dirasakan adanya permasalahan pembelajaran di suatu kelas. Penelitian tindakan kelas sebagai penelitian yang bersifat kolaboratif yang dilaksanakan dengan mengikuti prosedur yang menyatakan bahwa dalam satu siklus terdiri atas empat langkah: perencanaan, pelaksanaan, observasi, dan refleksi (Wardhani, 2007:21). Penelitian tindakan kelas ini menggunakan model penelitian tindakan dari Hopkins (Sanjaya, 2013:53) yang terdiri atas empat tahap, yaitu perencanaan (planning), pelaksanaan (acting), pengamatan (observing), dan refleksi (reflecting).

Teknik pengumpulan data pada penelitian ini adalah tes dan observasi. Tes adalah alat atau prosedur yang digunakan dalam rangka pengukuran dan penilaian di bidang pendidikan yang berbentuk pemberian tugas atau serangkaian tugas, baik berupa pertanyaan-pertanyaan, maupun perintah-perintah (Sudijono, 2009:67). Tes dalam penelitian ini digunakan untuk menilai kemampuan menulis teks persuasi siswa. Tes menulis teks persuasi dilakukan dua kali pada pertemuan kedua untuk tiap-tiap siklus dengan tema yang berbeda. Tes yang digunakan pada setiap siklus adalah tes tertulis atau penugasan kepada siswa untuk menulis teks persuasi seperti terlampir pada lampiran.

Observasi merupakan salah satu teknik pengumpulan data yang dapat digunakan dalam suatu penelitian. Menurut Purwanto (2011:149) observasi adalah metode atau cara-cara menganalisis dan mengadakan pencatatan secara sistematis mengenai tingkah laku dengan melihat atau mengamati individu atau kelompok secara langsung. Observasi pada penelitian ini dilakukan untuk mengetahui aktivitas siswa selama pembelajaran menulis teks persuasi berlangsung. Lembar observasi diisi oleh rekan sejawat yang bertindak sebagai pengamat.

Analisis data merupakan upaya yang dilakukan peneliti untuk mengolah data. Untuk menganalisis data penelitian, langkah-langkah yang dilakukan sebagai berikut.

1. Memberikan nilai atau skor terhadap teks persuasi yang ditulis siswa.

2. Penlaian kemampuan menulis teks persuasi dilakukan oleh peneliti sedangkan untuk pengamatan aktivitas siswa dalam pembelajaran menulis teks persuasi dilakukan oleh teman sejawat.

3. Menghitung rata-rata tes awal (pratindakan) nilai rata-rata tes akhir siklus pertama, dan nilai rata-rata tes akhir siklus kedua.

4. Menentukan rata-rata kemampuan menulis teks persuasi.

5. Menentukan klasifikasi kemampuan menulis teks persuasi.

6. Menentukan klasifikasi hasil pengamatan aktivitas belajar siswa.

7. Menghitung jumlah nilai siswa secara klasikal, yaitu menghitung jumlah siswa yang memperoleh nilai $\geq 70$.

Indikator keberhasilan dalam penelitian tindakan kelas ini harus memenuhi persyaratan sebagai berikut: 1) secara individual siswa dinyatakan berhasil jika 
memperoleh nilai kemampuan menulis teks persuasi minimal nilai $\geq 70$, dan secara klasikal $85 \%$ siswa memperoleh nilai rata-rata $\geq 70$, dan 2) aktivitas siswa dalam proses pembelajaran menulis teks persuasi dinyatakan berhasil jika memperoleh nilai dari minimal cukup aktif menjadi aktif atau sangat aktif.

\section{HASIL}

\section{Hasil Siklus I}

Hasil tes kemampuan menulis teks persuasi secara keseluruhan dalam kategori "cukup" dengan rata-rata 67, 98. Dari 32 siswa, 9 siswa yang memperoleh nilai dengan rentang 80 - 100 yang termasuk kategori "sangat baik", 7 siswa memperoleh nilai dengan rentang 70 - 79 dengan kategori "baik", 12 siswa memperoleh nilai dengan rentang 56 - 69 dengan kategori "cukup", 3 siswa memperoleh nilain dengan rentang 45 - 55 yang termasuk dalam kategori "kurang", dan 1 siswa yang memperoleh nilai dengan rentang 1 - 44 dengan kategori "sangat kurang".

Pada siklus I terdapat beberapa aspek yang belum tercapai pada siklus I ini, antara lain: (1) sebagian siswa menulis teks persuasi dengan menggunakan kalimat yang yang kurang tepat; (2) beberapa siswa terlihat belum memahami ciri kebahasaan masing-masing struktur teks persuasi; (3) beberapa siswa masih terlihat belum memahami apa yang harus dilakukan pada tahapan pembelajaran dengan teknik pemodelan; (4) beberapa siswa masih ada yang belum serius mengikuti pembelajaran, hal ini terlihat ketika ada beberapa siswa yang masih melakukan aktivitas lain selain aktivitas yang berkenaan dengan pembelajaran dengan menggunakan teknik pemodelan seperti bersenda gurau dengan teman, mengganggu teman yang lain, mencoret-coret kertas tugas, enggan belajar dalam kelompok; dan (5) indikator keberhasilan belum tercapai.

Berdasarkan uraian refleksi, bahwa nilai kemampuan menulis teks persuasi secara individual yang diperoleh pada siklus I yaitu 67.98 termasuk kategori "cukup", sedangkan secara klasikal, siswa yang memperoleh nilai $\geq 70$ belum mencapai $85 \%$, artinya bahwa nilai rata-rata siswa tersebut belum mencapai indikator keberhasilan yang telah ditetapkan. Indikator keberhasilan individual yang ditetapkan adalah niai rata-rata mencapai $\geq 70$, dan keberhasilan secara klasikal jika $85 \%$ siswa memperoleh nilai rata-rata $\geq 70$. Oleh karena itu, dapat dinyatakan bahwa tindakan pembelajaran pada siklus I belum berhasil, sehingga diperlukan adanya penelitian tindakan pembelajaran siklus berikutnya yaitu siklus II.

2. Hasil Siklus II

Siklus II terdapat 16 siswa yang termasuk dalam kategori sangat baik dengan rentang nilai 85-100 dengan presentase 50\%, termasuk dalam kategori baik sebanyak 14 siswa yaitu 43,75\% dengan rentang nilai 75-84, sedangkan rentang nilai 65-74 kategori cukup presentase 6,25\% sebanyak 2 siswa. kategori dengan rentang nilai 55-64 sebanyak 0 siswa atau $0 \%$, dan kategori sangat kurang dengan rentang nilai 0-54 sebanyak 0 siswa atau 0\%. Berdasarkan indikator penilaian secara indiviidu siswa yang mendapat nilai $\geq 70$ sebanyak 30 siswa yaitu 93,75\%, maka secara klasikal menulis teks prosedur belum tuntas pada pada siklus I ini. Hal ini dapat ditunjukkan pada tabel berikut.

Dari hasil analisis data tes kemampuan menulis teks persuasi menunjukkan hasil perolehan tes kemampuan menulis teks persuasi siswa siklus II. Secara keseluruhan, kemampuan menulis teks persuasi siswa dalam kategori "Baik" dengan rata-rata 79, 21. Dari 32 siswa, 13 siswa yang memperoleh nilai dengan rentang 80 - 
100 yang termasuk kategori "sangat baik", 15 siswa memperoleh nilai dengan rentang 70 - 79 dengan kategori "baik", 2 siswa memperoleh nilai dengan rentang 56 - 69 dengan kategori "cukup", 1 siswa memperoleh nilain dengan rentang 45 - 55 yang termasuk dalam kategori "kurang", dan 1 siswa yang memperoleh nilai dengan rentang 1 - 44 dengan kategori "sangat kurang".

Berdasarkan hasil perolehan nilai kemampuan menulis teks persuasi siswa pada siklus II ini, maka dapat dilihat adanya peningkatan nilai dari siklus I yang hanya mencapai rata-rata 67.98 dan termasuk dalam kategori "cukup", meningkat menjadi 79,21 pada siklus II yang termasuk pada kategori "Baik". Selanjutnya, berdasarkan pada nilai perolehan tersebut, maka indikator keberhasilan tindakan yang sudah ditetapkan sebelumnya dinyatakan sudah berhasil tercapai yaitu keberhasilan individu dengan rata-rata siswa memperoleh nilai $\geq 70$ dan keberhasilan klasikal jika $85 \%$ siswa telah mencapai nilai perolehan rata-rata $\geq 75$.

\section{PEMBAHASAN}

Penerapan teknik pemodelan mampu meningkatkan kemampuan menulis teks persuasi dan aktivitas belajar siswa kelas VIII SMP Negeri L. Sidoharjo Kabupaten Musi Rawas. Hal ini membuktikan bahwa teknik pemodelan yang diberikan oleh guru mampu memberikan semangat dan kemandirian kepada siswa dalam menulis teks persuasi karena diberikannya contoh pengembangan teks persuasi secara sistematis (Fitri, 2016:120). Peningkatan kemampuan menulis teks persuasi ini terjadi dari siklus 1 ke siklus 2. Nilai pada siklus I yang hanya mencapai rata-rata 67.98 dan termasuk dalam kategori "cukup", meningkat menjadi 79,21 pada siklus II yang termasuk pada kategori "Baik".

Pada siklus I, nilai rata-rata kemampuan menulis teks persuasi pada siklus I sebesar 67, 98 dengan persentase ketuntasan 46,88 \%. Hal ini mengindikasikan bahwa kemampuan menulis teks persuasi siswa berada dalam kategori "Cukup" pada rentang nilai 56 - 59. Hasil tersebut belum mencapai indikator keberhasilan yang telah ditentukan yaitu 70 . Dari 32 siswa, 9 siswa yang memperoleh nilai dengan rentang 80 - 100 yang termasuk kategori "Sangat Baik", 7 siswa memperoleh nilai dengan rentang 70 - 79 dengan kategori "Baik", 12 siswa memperoleh nilai dengan rentang 56 - 69 dengan kategori "Cukup", 3 siswa memperoleh nilai dengan rentang 45 - 55 yang termasuk dalam kategori "Kurang", dan 1 siswa yang memperoleh nilai dengan rentang 1 - 44 dengan kategori "Sangat Kurang". Artinya, aktivitas siswa dalam pembelajaran menulis teks persuasi dengan menggunakan teknik pemodelan belum termasuk aktif. Ada beberapa siswa yang benar-benar belum memahami cara menulis teks persuasi, hal ini terlihat dari aktivitas siswa yang masih melihat pekerjaan temannya. Berdasarkan refleksi siklus I, siswa memperoleh hasil menulis teks persuasi yang kurang memuaskan. Salah satu penyebabnya adalah siswa kurang aktif dalam proses mengamati dan mengidentifikasi aspek kebahasaan setiap struktur teks persuasi terutama dalam struktur kalimat pernyataan ajakan.

Pada siklus II diperoleh nilai rata-rata kemampuan menulis teks persuasi sebesar 79,21 dengan persentase ketuntasan $87,5 \%$. Hal ini mengindikasikan bahwa kemampuan menulis teks persuasi siswa berada dalam kategori "Baik" pada rentang nilai $70-79$. Dari 32 siswa, 13 siswa yang memperoleh nilai dengan rentang 80 - 100 yang termasuk kategori "Sangat Baik", 15 siswa memperoleh nilai dengan rentang 70 - 79 dengan kategori "Baik", 2 siswa memperoleh nilai dengan rentang 
56 - 69 dengan kategori "Cukup", 2 siswa memperoleh nilai dengan rentang 45 - 55 yang termasuk dalam kategori "Kurang".

Peningkatan perolehan hasil kemampuan menulis teks persuasi dari siklus I ke siklus II tersebut sesuai dengan tujuan diterapkannya teknik pemodelan dalam pembelajaran menulis teks persuasi. Hal ini dikarenakan tahapan-tahapan yang dilaksanakan dalam teknik pemodelan lebih menitikberatkan siswa untuk bepikir dan terlibat dalam proses penulisan teks persuasi. Keterlibatan tersebut dapat membuat siswa aktif, dan keaktifan siswa dalam mengamati, menanya, mengidentifikasi struktur teks persuasi dapat menjadikan kemampuan siswa dalam menulis teks persuasi juga meningkat.

Hal ini sejalan dengan tujuan diterapkannya teknik pemodelan seperti yang diungkapkan Nuryatin (2010:34) bahwa pemodelan dapat diartikan sebagai upaya pemberian model (contoh) yang berhubungan dengan materi dan aktivitas pembelajaran yang dilakukan siswa. Pemodelan harus dilakukan secara terencana agar memberikan sumbangan pada pemahaman dan keterlibatan siswa dalam proses pembelajaran, sehingga hasil belajar mengalami peningkatan.

Peningkatan kemampuan menulis teks persuasi tersebut, diikuti juga dengan meningkatnya aktivitas siswa dalam pembelajaran menulis teks persuasi. Peningkatan tersebut menunjukkan keaktifan dan keterlibatan langsung dalam melakukan pengamatan, Tanya jawab dan mengidentifikasi aspek kebahasaan dalam struktur teks persuasi yang akan diterapkan dalam menulis teks persuasi.

Peningkatan aktivitas siswa dalam pembelajaran menulis teks persuasi tersebut dapat dipengaruhi beberapa faktor salah satunya siswa lebih antusias belajar karena tertarik dengan teknik pembelajaran yang digunakan guru, terutama jika teknik tersebut belum pernah atau jarang digunakan oleh guru. Penerapan teknik pemodelan atau pemberian contoh teks persuasi secara langsung dapat meningkatkan aktivitas siswa dalam proses pembelajaran menulis teks persuasi.

Kelemahan yang ditunjukkan siswa dalam menulis teks persuasi dengan menggunakan teknik pemodelan adalah tidak cukupnya waktu dalam menyelesaikan tugas menulis teks persuasi. Hal ini sejalan dengan pendapat Nuryatin (2010:14) yang meyatakan bahwa kelemahan teknik pemodelan dalam pembelajaran menulis terletak pada kurangnya waktu. Dari peningkatan kemampuan menulis teks persuasi dan aktivitas siswa dalam pembelajaran menulis teks persuasi menunjukkan bahwa teknik pemodelan bukan hanya mampu meningkatkan keterampilan menulis iklan pada siswa kelas VII-D SMP 2 Wanadadi (Ernawati, 2009) melainkan juga mampu meningkatkan kemampuan menulis teks persuasi pada siswa kelas VIII SMP Negeri L. Sidoharjo Kabupaten Musi Rawas.

\section{KESIMPULAN DAN SARAN} bahwa:

Berdasarkan hasil penelitian dan pembahasan, maka dapat disimpulkan

1. Kemampuan menulis teks persuasi dengan menggunakan teknik pemodelan pada siswa kelas VIII.2 SMP N L. Sidoharjo Kabupaten Musi Rawas, terjadi peningkatan. Hal ini dapat dibuktikan dari hasil tindakan pembelajaran siklus I mencapai rata-rata 67, 98 yang termasuk dalam kategori "Cukup", meningkat menjadi 79, 21 pada siklus II yang termasuk dalam kategori "Baik".

2. Terjadi peningkatan aktivitas siswa dalam pembelajaran menulis teks persuasi dari siklus I ke siklus II. Hal ini dibuktikan pada siklus I, lima aspek pengamatan terhadap aktivitas pembelajaran menulis teks persuasi dari 32 
siswa dalam kategori "Cukup Aktif". Pada siklus II terjadi peningkatan karena aktivitas siswa dalam pembelajaran menulis teks persuasi dengan menggunakan teknik pemodelan dalam kategori "Aktif" ini terlihat dari lima aspek pengamatan aktivitas siswa yang meliputi ketelitian, keaktifan, kerja sama, tanggung jawab dan percaya diri secara klasikal sangat aktif.

\section{DAFTAR PUSTAKA}

Arikunto, S., Suhardjono, \& Supardi. (2012). Penelitian Tindakan Kelas. Jakarta : PT. Bumi Aksara.

Ernawati, K. (2009). "Peningkatan Keterampilan Menulis Iklan melalui Teknik Pemodelan pada Siswa Kelas VII-D SMP 2 Wanadadi Kabupaten Banjarnegara". Skripsi, Fakultas Bahasa dan Seni Universitas Negeri Semarang, https://lib.unnes.ac.id/2191/1/4294.pdf

Fitri, R. (2016). Penerapan Teknik Pemodelan untuk Meningkatkan Kemampuan Menulis Surat Resmi Siswa Kelas VIII SMP. Gramatika STKIP PGRI Sumatera Barat, 2(1). doi:10.22202/jg.2016.v2i2.1200

Mahsun. (2014). Teks Pembelajaran Bahasa Indonesia Kurikulum 2013. Jakarta: Raja Grafindo Persada.

Noermanzah \& Friantary, H. (2019). Development of Competency-Based Poetry Learning Materials for Class X High Schools. International Journal of Recent Technology and Engineering, 8(4), 6631.

Noermanzah, N. (2015). Peran Dosen Bahasa dan Sastra Indonesia dalam Mempertahankan Bahasa Indonesia sebagai Alat Pemersatu Negara Kesatuan Republik Indonesia pada Era Globalisasi. Dalam Prosiding Seminar Nasional Bulan Bahasa 2015. Unit Penerbitan FKIP Universitas Bengkulu, p. 274. http://repository.unib.ac.id/11133/

Noermanzah, N. (2019). Bahasa sebagai Alat Komunikasi, Citra Pikiran, dan Kepribadian. Seminar Nasional Pendidikan Bahasa dan Sastra, Prosiding Seminar Nasional Bulan Bahasa (Semiba) 2019, https://ejournal.unib.ac.id/index.php/semiba/article/view/11151

Nurhadi. (2004). Pembelajaran Kontekstual dan Penerapan dalam KBK. Surabaya: Universitas Negeri Malang.

Nuryatin, A. (2010). Mengabadikan Pengalaman dalam Cerpen. Rembang: Yayasan Adhigama.

Purwanto, N. (2011). Metodologi Pengajaran Bahasa Indonesia di Sekolah Dasar. Bandung: Rosda Jayaputra. 
Rahayu, S., \& Rochmiyati, S. (2019). Penerapan Tri-N dalam Buku Teks Siswa Bahasa Indonesia untuk Siswa SMP Kelas VIII Kurikulum 2013. Silampari Bisa: Jurnal Penelitian Pendidikan Bahasa Indonesia, Daerah, dan Asing, 2(2), 175. doi:10.31540/silamparibisa.v2i2.594

Ramadania, F. (2016). Konsep Bahasa Berbasis Teks pada Buku Ajar Kurikulum 2013. STILISTIKA: Jurnal Bahasa, Sastra, dan Pengajarannya, 1(2). doi:10.33654/sti.v1i2.372

Sahri, A. (2015). Implementasi Pendidikan Karakter secara Terintegrasi dalam Pembelajaran Menulis Karangan Deskripsi di Kelas XI TIK SMK Negeri 2 Kepahiang. Diksa: Pendidikan Bahasa dan Sastra Indonesia, 1(2), 66. doi:10.33369/diksa.v1i2.3181

Sanjaya, W. (2013). Penelitian Tindakan Kelas. Jakarta: Kencana Prenadamedia Group.

Sudijono, A. (2009). Pengantar Statistik Pendidikan. Jakarta: Rajawali Pers.

Suryani, N. K. I., Putrayasa, I. B., \& Astika, I. M. (2014). Penerapan Teknik Pemodelan untuk Meningkatkan Keterampilan Menulis Paragraf Persuasi pada Siswa Kelas X3 SMA Negeri 1 Kubu. Jurnal Pendidikan Bahasa dan Sastra $\begin{array}{lrr}\text { Indonesia } & \text { (JPBSI) 2(1), 2-3, }\end{array}$

https://ejournal.undiksha.ac.id/index.php/JJPBS/article/view/3285

Tabelessy, N. (2019). Kreativitas Menulis Karangan Persuasi Siswa SMP. Jurnal Tahuri, 16(2), 44. doi:10.30598/tahurivol16issue2page35-46

Wardhani, I. dkk. (2007). Penelitian Tindakan Kelas. Jakarta: Universitas Terbuka. 